\title{
Dinámicas de construcción temprana de la ciudadanía de la población afrodescendiente en Costa Rica, 1880-1924
}

\author{
Mauricio Menjívar Ochoa ${ }^{2}$
}

Recibido: 18 de mayo de 2020 / Aceptado: 28 de septiembre de 2020

Resumen. En el artículo se analiza la participación de hombres afrocaribeños como funcionarios en la estructura burocrática del Estado en la provincia de Limón, Costa Rica, en diferentes cargos locales, con el fin de discutir la relevancia de este fenómeno como un antecedente de la construcción de la ciudadanía de los afrodescendientes en dicha provincia en el período 1880-1924. Esto es relevante dado que la normativa impedía a los extranjeros desempeñarse como funcionarios públicos y, sin embargo, en una sociedad racista como la costarricense, hombres afrodescendientes de origen jamaiquino ocuparon dichos cargos. La investigación procura comprender este fenómeno analizando la legislación de la época que regulaba los puestos públicos estudiados, la participación de esta población en dichos puestos, así como el papel que jugaron sus comunidades en el acceso a dicha institucionalidad. A partir de las fuentes disponibles se concluye, preliminarmente, que la incorporación de hombres afrocaribeños a la función pública en Limón corrió de la mano de un doble mecanismo: los esfuerzos comunales por su contratacion, por una parte, y el interés del Estado por contratarles, por otra. También concluye que, si bien la incorporación como funcionarios del Estado no devino automáticamente en la ciudadanía formal, sí abrió espacios para el ejercicio de ciertos derechos destinados, en principio, solamente a los costarricenses.

Palabras clave: Ciudadanía; afrodescendientes; funcionarios del Estado; Caribe; Costa Rica; siglos XIX-XX.

\section{[en] Dynamics of the Early Construction of Citizenship of the Afrodescendant Population in Costa Rica, 1880-1924}

\begin{abstract}
This article analyzes the participation of Afro-Caribbean men as officials in different local officees within the bureaucratic structure of the State in the Province of Limón, Costa Rica, in order to discuss the relevance of this phenomenon as a background for the construction of citizenship of the afrodescendants in said province, between 1880 and 1924. In a racist society such as that of Costa Rica, this is relevant because afrodescendant men of Jamaican origin held public offices, notwithstanding the regulations that impeded foreigners from occupying these positions. The research seeks to comprehend this phenomenon by analyzing the contemporary legislation that regulated the public positions

1 Resultado del proyecto No. 024-B8-207, inscrito en la Escuela de Estudios Generales de la Universidad de Costa Rica (UCR), con vigencia del 01 de febrero de 2018 al 01 de febrero de 2020. También tuvo lugar en el proyecto "Mundos conectados: el Caribe, origen del mundo moderno", bajo la dirección de la profesora Consuelo Naranjo Orovio (Instituto de Historia-CSIC), proyecto que ha recibido fondos del programa de investigación e innovación Horizon 2020 de la Unión Europea en virtud del acuerdo de subvención Marie Sklodowska Curie N. ${ }^{\circ} 823846$. Un bosquejo preliminar fue presentado en el II Simposio Internacional "El significado de la negritud" (15 al 19 de febrero de 2016), organizado por la Cátedra de Estudios de África y el Caribe de la UCR. Me gustaría agradecer a la Licda. Gabriela Carrión por la revisión que hizo de este trabajo.

2 Escuela de Estudios Generales de la Universidad de Costa Rica.

E-mail: mauricio.menjivar@ucr.ac.cr
\end{abstract}


studied and the participation of the afrodescendant population in these offices, as well as the role their communities played in acquiring access to the institutions. Based on the available sources, a preliminary conclusion is that the incorporation of Afro-Caribbean men into the public service in Limón was due to two mechanisms: on the one hand, their communities' efforts in favor of their contracts and, on the other, the State's interest in contracting them. It is also concluded that although their incorporation as officials of the State did not automatically result in formal citizenship, it opened new spaces for their exercise of certain rights that were reserved, in principle, only to Costa Ricans.

Keywords: Citizenship; Afrodescendants; State Officials; Caribbean; Costa Rica; $19^{\text {th }}-20^{\text {th }}$ Centuries.

Sumario. 1. Introducción. 2. Las personas afrodescendientes en Limón: una caracterización general. 3. Exclusión, inclusión y ciudadanía de las personas afrodescendientes en las ciencias sociales: ejemplos del estado de la cuestión en Costa Rica. 4. Los funcionarios públicos en el contexto de la centralización del Estado: una revisión de la normativa. 5. Los afrocaribeños: funcionarios del Estado en la provincia de Limón. 6. La construcción de la ciudadanía: un proceso contradictorio. 7. Conclusiones. 8. Referencias bibliográficas.

Cómo citar: Menjívar Ochoa, M. (2021) Dinámicas de construcción temprana de la ciudadanía de la población afrodescendiente en Costa Rica, 1880-1924, en Revista Complutense de Historia de América 47, 209-231.

\section{Introducción}

En el año 1906, Santiago Carlos Hilead, hombre de cincuenta años de edad, nacido en Saint Thomas, Jamaica, declaró ante el Juzgado Civil y del Crimen de Limón, Caribe de Costa Rica, que él había ido a capturar a David Delgado, pues éste había dado un machetazo al también costarricense José Rojas ${ }^{3}$.

¿Qué hacía un jamaiquino, con seguridad afrocaribeño, persiguiendo a un asesino, en este caso un costarricense del Valle Central? ¿Por qué un hombre negro capturaba a un mestizo costarricense en un país racista como la Costa Rica de inicio del siglo XX y, aún más, lo declaraba frente a un juzgado?

El cuadro estará más completo si decimos que Hilead persiguió al ofensor en su calidad de juez de paz. Ello, sin embargo, no contribuye a disminuir nuestra perplejidad, pues se trata de un cargo que, según la normativa, podía ser otorgado a un ciudadano, es decir, a un costarricense. No obstante, como la historiadora Lara Putnam ha señalado "en el Limón de principios del siglo XX, los inmigrantes afrocaribeños eran con regularidad designados como jueces de paz [...]. Otros inmigrantes afrodescendientes fueron contratados como policías"4. Como se verá, eso sucedió aún antes de ese momento, lo que abrió a los afrocaribeños a participar en los procesos de construcción del Estado, como bien ha señalado Putnam.

Ahora bien, en consonancia con lo anterior, en este trabajo tengo la intención de exponer algunas evidencias sobre la participación de hombres afrocaribeños dentro de la estructura burocrática del Estado en la provincia de Limón, más específicamente, como jueces de paz, policías, comisarios, intérpretes y "empíricos", con el fin de discutir la relevancia de este fenómeno para construir, de manera temprana,

3 Juicio por homicidio contra David Delgado. Costa Rica, 1914. Archivo Nacional de Costa Rica [Costa Rica] (en adelante ANCR). Limón Juzgado Civil y del Crimen (en adelante LJCC), Exp. 912, f. 12.

4 Putnam, s.f.: 28. 
la ciudadanía de los afrocaribeños en esta provincia. El período que comprende mi investigación va de 1880 a 1924 por varios motivos: primero, en este período se experimenta un modelo de explotación extensiva de la tierra e intensiva de la mano de obra vinculada a la producción bananera; segundo, el primer año es parte de un tiempo en el que se produce una significativa migración jamaiquina hacia el Caribe centroamericano 5 ; tercero, en 1924 existe un importante interés del Congreso Nacional en incrementar la oferta de mano de obra en el Caribe costarricense, plasmado en la reducción del arancel de entrada a inmigrantes, en su mayoría afrocaribeños ${ }^{6}$. Esto último permite sostener cierta apertura de las autoridades nacionales hacia la población afrocaribeña que labora en Limón ${ }^{7}$. No fue inusual la apertura de la élite laboral hacia la contratación de funcionarios de diversos orígenes, pero no deja de sorprender una actitud, en el mismo sentido, de personas sobre las que ya recaían leyes racistas como la que, en 1862, prohibió otorgar tierras a inmigrantes de "raza africana o china"s.

Así, para avanzar en la exploración del vínculo entre contratación de hombres afrocaribeños e integración asociada a la ciudadanía, por la vía de la contratación en las funciones del Estado en lo local, el artículo se estructura en siete partes, además de ésta. En la segunda parte, busco caracterizar en términos muy generales a la población afrocaribeña, particularmente a la jamaiquina, en suelo costarricense, a la vez que discuto su categorización. En la tercera parte, realizo un balance de los trabajos publicados, a mi parecer más relevantes, que abordan la cuestión de la ciudadanía afrodescendiente en Costa Rica para el período estudiado. En la cuarta, llevo a cabo una revisión de la normativa que reguló a los funcionarios públicos en la segunda mitad del siglo XIX. En la quinta, expongo la labor de los funcionarios afrodescendientes y algunos mecanismos que pudieron contribuir a su inserción en la institucionalidad de la Comarca de Limón. En la sexta sección, procuro poner en perspectiva teórica algunas vías por las que pudo correr la construcción de la ciudadanía, según lo estudiado. En la séptima parte, correspondiente a las conclusiones, realizo una discusión general sobre los resultados.

\section{Las personas afrodescendientes en Limón: una caracterización general}

La provincia de Limón, Caribe costarricense, desde la década de 1870 y hasta 1900, estuvo fuertemente marcada por la dinámica que imprimieron la construcción del ferrocarril y el ingreso de la producción bananera en manos de la United Fruit Company (UFCo) ${ }^{9}$. Entre las implicaciones de estas industrias, figuró la atracción de migrantes afrocaribeños, quienes se vincularon a los circuitos de migración entre Jamaica y Costa Rica ${ }^{10}$. En este flujo migratorio incidieron las duras condiciones poscoloniales de sus lugares originarios, entre ellas, la baja de los salarios producto

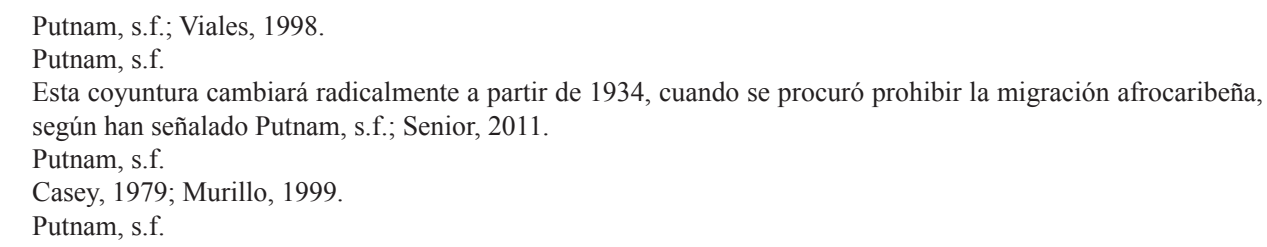


de la contratación de trabajadores provenientes de la India, a quienes en Jamaica se pagaba una sexta parte de los salarios antes vigentes ${ }^{11}$.

El país de procedencia de la mayoría de las personas migrantes afrocaribeñas en Limón fue Jamaica, movimiento que fue registrado desde $1872^{12}$. Este proceso migratorio tuvo gran importancia en el perfil de la población de limonenses en los años venideros; en 1883, al inicio de nuestro período de estudio, el $47 \%$ era considerada negra y el $68,5 \%$, extranjera ${ }^{13}$. Fue el período que va de 1905 a 1919 el de mayor intensidad de llegada de antillanos ${ }^{14}$. Su importancia en Limón fue tal que, en 1904, de un total de 5600 trabajadores reportados por la UFCo, 4000 eran jamaiquinos ${ }^{15}$. Y aunque la migración de Jamaica a Costa Rica tendió a disminuir con posterioridad, en 1927 los jamaiquinos significaron una proporción nada despreciable de la población limonense $(28 \%)^{16}$. Para este mismo año, en Limón se configuró una población con un fuerte predominio de personas consideradas "negras" (54\% de la población) y extranjeras (69\%), con un alto índice de masculinidad (120,7 hombres por cada 100 mujeres), en su mayoría jóvenes (una edad promedio de 26,6 años), y con afrocaribeños que se desempeñaron principalmente como empleados (predominante en el sector agrícola) o en trabajos por cuenta propia ${ }^{17}$.

Una caracterización de las personas afrocaribeñas, particularmente las de origen jamaiquino, en la provincia de Limón no podría prescindir de los elementos culturales e identitarios. Entre estos destacan, para el período estudiado, el habla del idioma inglés -enriquecido por aportes de diferente procedencia- y la práctica, en un país predominantemente católico, de las religiones con raíz protestante, ya se tratase del anglicanismo, el baptismo o el metodismo ${ }^{18}$. Además, y como veremos adelante, varios autores y autoras han puesto de relieve el sentimiento de fuerte apego al Imperio británico por parte de las personas de origen jamaiquino, quienes -como parte de su identidad nacional- se reafirmaron como súbditos británicos. Éste es un elemento particularmente interesante si se considera que, al mismo tiempo, en este artículo discuto la posibilidad de encontrar evidencias de un muy temprano esfuerzo de integración a la dinámica ciudadana de Costa Rica. Considero que ésta es parte de las contradicciones y de la riqueza de un proceso social que es a la misma vez formal y cultural.

Un último aspecto de la caracterización del origen de las personas aquí estudiadas profundiza en lo político y en lo ideológico en cuanto al lugar de enunciación de quien escribe. El asunto se puede condensar en la siguiente pregunta: al referirnos a esta población ¿deberíamos hablar de "afrodescendientes" o de "negros"? La pregunta es compleja y espinosa: a la categoría de "afrodescendiente" se le puede criticar al menos tres aspectos. El más evidente es que no toda la gente que habita África es fenotípicamente igual, de ahí que el término se diluiría en su intención clasificadora. El segundo aspecto alude al proceso de mestizaje entre la población

1 Viales, 1998.

12 Duncan - Meléndez, 2005. Viales, 1998, por otra parte, afirma que es posible rastrear la llegada de extranjeros a Limón desde 1863, seguramente en otro tipo de actividades económicas.

13 Senior, 2011. Muchas otras nacionalidades también fueron atraídas a Limón en este período, como señala Murillo, 1999.

14 Viales, 1998.

15 Senior, 2011.

16 Viales, 1998.

17 Ibídem.

18 Duncan, 2001 
esclavizada que vino a las Américas, la población indígena y la europea, lo que podría llevar a sostener que, en ese sentido, todos y todas quienes somos producto de ese proceso somos "afrodescendientes" 1 . El tercero es la reivindicación del uso de la categoría "negro" o "negra" como referente identitario por algunas personas que son parte de la intelectualidad y de la militancia "negra" en Costa Rica. Mitzy Barley, mujer negra costarricense, una vez me indicó que, para ella, África no tenía referente identitario alguno, y que la denominación "afro" alejaba, política e ideológicamente, a las personas negras de su origen costarricense. Aunque sin una reflexión de tal profundidad, también es posible escuchar a personas, en Costa Rica, denominarse a sí mismas y a otros de diferentes nacionalidades, como "negros". En el 2006, durante un trabajo de campo que realicé en el Caribe sur de Costa Rica, un informante, al señalar los orígenes de los pobladores de Puerto Viejo, decía: "nosotros los negros", "aquél es un negro panameño", "aquél es un negro de por aquí". Esta noción identitaria refuerza el argumento brindado por Barley.

No obstante, existen otras académicas que reivindican lo "afro" como una manera válida de referirse a esta población. En este sentido, la intelectual afrocostarricense Diana Senior Angulo ${ }^{20}$ retoma las categorías "afrocostarricense", "afrocaribeño/a" y "afrodescendiente" para dar cuenta de procesos históricos específicos vinculados a su ascendencia y a su nacimiento. Recuerda, además, que "negro/a fue la etiqueta de control social (opresión) y estigmatización conferida a la población de origen africano que vino a este continente a trabajar de manera forzada en condición de esclavitud. De utilizarla de forma estricta, estaríamos de acuerdo en la existencia de la raza negra, y por ende de la amarilla, blanca y roja, como en su momento la comunidad intelectual y científica estimó válido y pertinente"21.

Así, comparto el punto de partida de Senior cuando señala que "lo afro constituye una nueva forma de nombrar e dientificar a esta población, reinvindicando su origen ancestral y dignificándola dentro de las sociedades contemporáneas"22, sus sociedades contemporáneas, se podría enfatizar. Pensando en estos argumentos, y sin pretender restar la validez que para muchas personas tiene la categoría "negro" como referente identitario, en este trabajo he optado por usar las categorías "afrocostarricense", "afrocaribeño/a" y "afrodescendiente" para referirme, como investigador, a quienes fueron parte de los procesos históricos a los que Senior alude, y que aquí se vinculan a la discusión sobre los tempranos y muy incipientes procesos de construcción de su ciudadanía en suelo costarricense.

\section{Exclusión, inclusión y ciudadanía de las personas afrodescendientes en las ciencias sociales: ejemplos del estado de la cuestión en Costa Rica}

Una pregunta que resulta relevante al revisar una parte de la historiografía dedicada a la población afrodescendiente en Costa Rica tiene que ver con el lugar que ésta otorga a la construcción de la ciudadanía y, en general, a su inclusión dentro del proyecto de Estado nacional antes de 1949. En el imaginario nacional, este año es un

19 Agradezco profundamente a la Dra. Rina Cáceres Gómez haber compartido conmigo este argumento, que ha sido fundamental para definir mi posición sobre este asunto tan crucial.

20 Senior, 2011.

21 Ibídem: XVI.

22 Ibídem. 
parteaguas que marca el momento a partir del cual se hizo posible la ciudadanía de la población afrodescendiente por la vía legal, gracias a las gestiones de José Figueres Ferrer. Debe decirse que 1949 es el año en el que Figueres Ferrer presidió la Junta Fundadora de la Segunda República, luego de que su bando resultara triunfador de la guerra civil de 1948. Estos antecedentes permitirían que esta importante figura, al frente de su partido, el Liberación Nacional, ganara la presidencia en 1953, en la cual atrajo a los ahora votantes afrocostarricenses.

Así pues, ¿cómo visualiza la historiografía el proceso de construcción de la ciudadanía en este período que llamaremos temprano? Si bien las visiones no son del todo homogéneas, podrían distinguirse dos tendencias: la de quienes tienden a hacer un balance negativo respecto de un proceso temprano de gestión de la ciudadanía, y la de quienes tienden a encontrar indicios de la integración a la comunidad nacional aún antes de 1950. Me interesa destacar, a continuación, los ejemplos más significativos de estas tendencias.

Quizá una de las visiones menos optimistas sea la de Quince Duncan en la ya clásica obra El Negro en Costa Rica ${ }^{23}$. En este texto, el autor privilegia el contexto de la exclusión impulsada desde el país receptor y la autodiferenciación étnica y nacional de los emigrantes y sus descendientes. Esto le lleva a sostener que la situación de la población afrodescendiente no apuntó hacia la integración. En este sentido, Duncan, refiriéndose a la segunda generación de afrodescendientes en Costa Rica, señala que:

1948 encuentra al negro postrado. Las ideas de Garvey, la promesa de un amanecer nuevo ha quedado trunca con la muerte del caudillo. No son costarricenses. No son jamaiquinos. La Gran Bretaña no los reconoce como ciudadanos, porque han nacido en un país extranjero. Costa Rica no los reconoce como ciudadanos porque son negros, hijos de jamaicanos. Los negros de la segunda generación son, durante mucho tiempo, gente sin patria, sin identidad reconocida ${ }^{24}$.

De esta suerte, el planteamiento de Duncan no reconoce identidad para los nuevos ciudadanos hacia 1950. A mi criterio, el planteamiento de la antropóloga e historiadora Carmen Murillo ${ }^{25}$ es heredero, aunque con matices, de esta postura. Murillo analiza la importancia del componente jamaiquino dentro de la afroetnicidad en el Caribe costarricense, mostrando la compleja identidad de la población afrodescendiente debido a sus múltiples referentes identitarios: África, Jamaica, el protestantismo, el idioma y el Imperio británico. Para ella, tales referentes dificultaron el proceso de arraigo a Costa Rica, a lo cual se sumaron concepciones y medidas racistas de la población y del Estado. Ejemplos de ello son la Ley de Bases y Colonización de 1862, en la que se establece que aquélla se ubica entre las "razas prohibidas", y el Reglamento de Inmigración de $1942^{26}$, entre otras disposiciones. Esto significó una traba permanente a "la asignación de derechos ciudadanos" 27 . De esta suerte, y si bien la categoría central de su análisis no es la de "ciudadanía" de los afrocaribeños en Costa Rica, resulta importante anotar que para el período anterior a 1950 la autora enfatiza tanto en la construcción de una identidad que mira fuera de las fronteras

\footnotetext{
Duncan - Meléndez, 1981.

Ibídem: 116.

Murillo, 1999.

Ibídem: 199.

Ibídem: 201.
} 
costarricenses como en un Estado que promueve su exclusión. Ello parece sugerir un significativo desencuentro entre esta población y el Estado.

Ronald Harpelle ${ }^{28}$ también analiza algunos de los procesos de exclusión dirigidos a la comunidad afrocaribeña en Limón así como los procesos de construcción de su ciudadanía en la primera mitad del siglo XX. Para el autor, en el contexto de las políticas y concepciones racistas de Costa Rica, la ciudadanía se constituiría en un medio importante de sobrevivencia para los miembros de la comunidad ${ }^{29}$. No obstante, por motivos culturales este proceso no pareciera ser el mejor desde la perspectiva de Harpelle, pues contribuyó a alienar a los "West Indians" de su propia comunidad, sin lograr una condición de ciudadanía en igualdad de condiciones que el resto de la población ${ }^{30}$. Así pues, a su juicio los afrocaribeños no eran "West Indian" ni costarricenses; y sin embargo, aunque no sin cierta decepción, la argumentación de Harpelle lleva a reconocer la volición de estos actores que, a diferencia de Duncan, son sujetos que eligen y luchan por la admisión como costarricenses de manera temprana ${ }^{31}$.

Con las mismas preocupaciones de Duncan, Murillo y Harpelle, pero enfocada en el cantón Central de San José, Leidy Alpizar ${ }^{32}$ estudia la "inserción social" de los jamaiquinos en el período 1904-1950. Alpizar explicita el carácter contradictorio de esta inserción, señala que los jamaiquinos "por un lado se consideraron súbditos británicos y con rasgos culturales de influencia inglesa, como: conservar el idioma inglés, asistencia a iglesias protestantes y a organizaciones sociales afrocaribeñas. Por el otro, buscaron integrarse a la sociedad capitalina, por medio de la educación, los trabajos, hablar y escribir en español, adopción del catolicismo" "33.

En el primer argumento de Alpizar, puede verse la línea de preocupación de Duncan y Murillo, y en el segundo, la el de Harpelle. Sin embargo, además de la importancia de enfocarse en un espacio geográfico distinto al del Caribe, a mi criterio logra un mejor balance analítico al entender la relevancia que las estrategias -por definición deliberadas- vinculadas con lo laboral, lo familiar, lo religioso -la transición del protestantismo al catolicismo-y lo idiomático, tuvieron para la integración social de los jamaiquinos.

Omar Hernández, por otra parte, se aboca a "la participación de los afrocaribeños en el seno de la sociedad costarricense" 34 en el período 1949-1998. También Hernández comparte el punto de partida que ubica a 1949, luego de la guerra civil de 1948, como el parteaguas de la ciudadanía afrocaribeña en el país. Para él, es a partir de este momento que "se da a los inmigrantes antillanos nacidos en el país, el derecho de acceso directo a la ciudadanía" ${ }^{35}$. Lo interesante de su planteamiento es que pone de relieve "las acciones de los afrocaribeños en el campo de juego de la construcción del Estado-nación costarricense" ${ }^{" 36}$ en el período de su interés.

Trabajos más recientes indagan en las vías de construcción de la ciudadanía de la población afrocaribeña en el país a partir de la segunda mitad del siglo XX. Uno

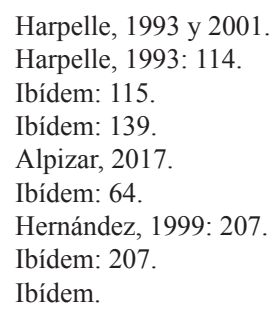


de ellos es el de Mónica Pérez Granados ${ }^{37}$, quien enfatiza en la manera en que se ha construido su condición jurídica en el período que corre entre 1949 y 2014. La autora señala que son las reformas "a las leyes de migración y extranjería y lo establecido en la Constitución" lo que otorga "igualdad jurídica a todas las minorías extranjeras residentes en el país que quisieran naturalizarse y a sus hijos el derecho de reclamar su ciudadanía por haber nacido en suelo costarricense" 38 . A juicio de Pérez, éste es el punto de inflexión para la población afrocaribeña naturalizada en la medida que aquí inició "un largo camino para lograr hacer efectivos sus derechos, que [sic] la nueva situación jurídica les permite" 39 . De esta suerte, Pérez se inscribiría, junto con Duncan y Murillo, entre quienes enfatizan en los procesos de construcción de la ciudadanía a partir de la segunda mitad del siglo XX.

En la misma línea anterior, la investigación de Reina Rosario Fernández ${ }^{40}$ encuentra que con posterioridad a la Guerra Civil de 1948 hay una inflexión en las políticas del Estado costarricense, que "por primera vez" controló políticamente la provincia, "derogó leyes racistas y ofreció formas de obtener la ciudadanía por diferentes vías" jurídica" 42 , y aplicó políticas integracionistas que devinieron en asimilacionistas ${ }^{43}$.

Me parece que, hasta ahora, uno de los trabajos más significativos y sistemáticos sobre la ciudadanía de la población afrocaribeña en Costa Rica es el de la historiadora afrocostarricense Diana Senior Angulo ${ }^{44}$, quien estudió el período comprendido entre 1927 y 1963, con lo que rompe la lógica del año 1948 como parteaguas de la integración. La autora estudia la legislación racista de las gestiones gubernamentales de León Cortés y Calderón Guardia, así como la significación de José Figueres Ferrer en la aceleración de la naturalización de la población negra. A juicio de nuestra autora, en el accionar de Figueres Ferrer existe un criterio de oportunidad: incluir a la población afrocaribeña naturalizada en su proyecto político para garantizar su fidelidad electoral ${ }^{45}$.

Por otra parte, Senior estudia las propias gestiones de dicha población en estos dos grandes momentos (antes y después de 1950). En un marco institucional especialmente adverso, antes de 1950, "la cédula de identidad se convirtió en el documento que por excelencia les acreditaría como miembros de la sociedad costarricense"46. De aquí que surgieran respuestas individuales y colectivas para legalizar su situación jurídico-civil, señala la autora. Si bien el grueso de la población naturalizada durante el período por ella estudiado lo hizo luego de 1949, lo cierto es que de la totalidad de afrocaribeños nacionalizados en el período 1927-1963, aproximadamente un 30\% (2462 personas $)^{47}$ lo hizo de manera temprana. Esto es relevante dadas las medidas racistas ya señaladas. Senior concluye que este proceso de naturalización es com-

\footnotetext{
Pérez, 2018.

Ibídem: 17.

Ibídem.

Rosario, 2014.

Ibídem: 278 .

Ibídem.

Ibídem.

Senior, 2011.

Ibídem: 238.

Ibídem: 237.

Ibídem: 168.
} 
plejo y en continua negociación "con la hibridez" entre sus aspectos identitarios afrocaribeños y costarricenses.

De los múltiples aportes del trabajo de Senior quisiera retomar dos, uno empírico y otro teórico. El empírico es la constatación de la agencia de muchas y muchos afrocaribeños para conseguir la ciudadanía en el período que he denominado como período temprano de la ciudadanía (antes de 1927). El segundo es que el trabajo apunta a un elemento teórico fundamental: la ciudadanía se construye desde arriba, es decir, a partir del accionar de la institucionalidad -ya sea obstaculizando o facilitando los mecanismos-, pero también desde abajo - con la acción de los agentes interesados.

Para iniciar con este movimiento de pinza que implica la construcción de la ciudadanía, describiré el panorama relacionado con el movimiento desde "arriba", es decir, lo que señala la legislación costarricense de la segunda mitad del siglo XX sobre la posibilidad de integrar a los extranjeros al servicio público en lo local, tarea que continuaré al revisar los casos concretos del ejercicio de esa función por hombres afrocaribeños.

\section{Los funcionarios públicos en el contexto de la centralización del Estado: una revisión de la normativa}

Por ahora, la normativa que regula a los sujetos de mi interés, que he podido encontrar, es aquélla en la que se define el papel de los funcionarios en labores policiales -jueces de paz, comisarios y policías-, y no así la de secretarios, intérpretes y "empíricos" -todas ellas labores en las que se desempeñaron hombres afrodescendientes, hasta donde me ha sido posible ubicar en las fuentes de archivo. En el caso de los jueces de paz, es posible ubicar sus regulaciones en el Reglamento de Policía de $1849^{48}$, al final de la primera administración del presidente José María Castro Madríz (1847-1849). Dicha administración se sitúa en los albores del período en que el historiador costarricense David Díaz Arias ubica "la era de la centralización" en Costa Rica, que va de 1848 a 1870. Este período cubre, además, la administración de Juan Rafael Mora Porras y los segundos períodos del mismo Castro Madriz -1866-1868y de Jesús Jiménez Zamora -1869-1870 49 .

Entre 1848 y 1870, este momento de centralización política es una etapa de consolidación del Estado que corre paralela a la consolidación del capitalismo agrario con el cultivo del cafés ${ }^{50}$. Uno de los rasgos del proceso de centralización política del período es el fortalecimiento del Poder Ejecutivo, el cual necesitó del enfrentamiento con los localismos -ya iniciado con anterioridad por Braulio Carrillo ${ }^{51}$ y de la capacidad de articulación de un proyecto de institucionalidad pública. Esto significó el modelaje de un Poder Ejecutivo autoritario con pretensiones de supeditación del Poder Legislativo y del Poder Judicial ${ }^{52}$. Con particular importancia en el período del presidente Mora, se experimentó una creciente restricción al poder municipal, lo que tenía como propósito la expansión del Estado ${ }^{53}$. A partir de 1870, la administración

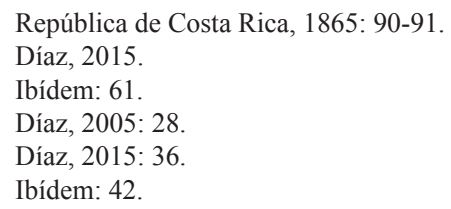


del Estado crecerá, y ello se concretará en el aumento de las oficinas públicas y en la contratación de burocracia que asumió las nuevas funciones estatales ${ }^{54}$.

El espíritu de este proceso, que mina lo local a favor de la centralización del poder, es claro en el ya citado Reglamento de Policía de 1849. En primer término, se deben explicar las jerarquías de la policía que sigue el orden político-administrativo del país, igualmente jerarquizado en nacional, provincial, cantonal y parroquial o distrital. Así, la policía estaba a cargo de los gobernadores, "quienes la desempeñan por sí en sus respectivas Provincias y por medio de Comisarios y Agentes" siones, la jefatura de policía podría estar separada de las funciones del gobernador, aunque subordinadas a éstas. Gobernadores y policías, debe decirse, eran nombrados directamente por el Poder Ejecutivo. A la orden del gobernador se encontraba el jefe político, que era la máxima instancia de la policía en el nivel cantonal y, dependiendo del jefe político, encontramos finalmente a los jueces de paz, quienes eran "agentes de policía en sus parroquias" "56. A pesar de que el jefe político y el juez de paz dependían del gobernador, sus atribuciones en materia de policía eran conferidas por el jefe de policía ${ }^{57}$.

En los cantones y parroquias de ciertas provincias, los gobernadores contarían, además, con "gendarmes" -posiblemente una forma de designar a los policías-a fin de que siguiesen las órdenes de los jefes políticos y de los jueces de paz ${ }^{58}$. La posibilidad de asignar estos gendarmes a los gobernadores era criterio del Poder Ejecutivo.

Es decir, los jueces de paz y los "gendarmes" tenían como ámbito de operaciones lo local, y recibían instrucciones no sólo de los jefes políticos, sino de los jueces de paz $^{59}$. Estos últimos tenían una gama muy amplia de atribuciones: el cuido "de la moral pública" -la cual incluía el respeto a los dogmas y el culto religioso, el castigo a los corruptores de la juventud y el cuido de ésta, la obediencia de los hijos a los padres, la persecución de los juegos prohibidos-, la salubridad, la promoción de la beneficencia y la seguridad pública, entre otras ${ }^{60}$.

En la Constitución de 1859, el decreto del presidente Mora Porras de 1857, que había establecido que sólo habría municipalidades en las cabeceras de provincia, se elevó a rango constitucional ${ }^{61}$, nuevo testimonio de la concentración del poder en el Ejecutivo a expensas del poder municipal. Esto se tradujo en los esfuerzos de codificar la legislación municipal en las ordenanzas municipales de 1862 y 1867. Precisamente en las Ordenanzas Municipales de $1862^{62}$ se establecieron algunas regulaciones adicionales a los jueces de paz. Entre las más importantes se encuentra la delimitación de sus funciones, entre ellas, funciones judiciales, así como "prevenir é impedir los delitos, procediendo de oficio, por sí mismos, ó dictando órdenes a sus agentes para la investigación de los crímenes y captura de los delincuentes, poniendo estos inmediatamente á disposición de la autoridad competentes, é informando oportunamente del resultado de sus investigaciones y de las de sus agentes"63.

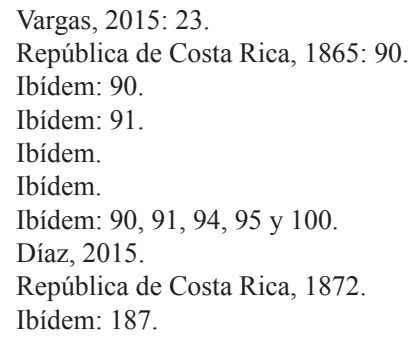


Los jueces de paz continuaron dependiendo de los jefes políticos y de los gobernadores, pero -como puede apreciarse en la cita anterior-se institucionaliza la figura de los comisarios, subordinada al juez de paz. Es posible que estos comisarios fueran llamados gendarmes o policías en la práctica propia de los distritos. En las Ordenanzas de 1867 son llamados comisarios de policía ${ }^{64}$.

Como señalé anteriormente, en 1849 se preveía que, eventualmente, el Ejecutivo designaría "gendarmes" que seguirían las órdenes de jefes políticos y jueces de paz. De tal suerte, que en las Ordenanzas de 1862 se institucionalizara la figura parece consecuente con la tendencia del crecimiento del aparato administrativo del Estado y la consiguiente contratación de más funcionarios. El comisario cooperaría en la ejecución de las leyes y reglamentos de policía, velaría por la ejecución de obras públicas a encargo de los jueces de paz, vigilaría el cumplimiento de acuerdos y órdenes municipales (Art.110), además de "perseguir y aprehender á las personas halladas infraganti delito, conduciéndolas inmediatamente á presencia del Juez de Paz ó autoridad competente; exigiendo si fuese necesario, el auxilio de la fuerza armada y recogiendo las piezas o instrumentos que puedan servir para la comprobación del cuerpo del delito" 65 .

Tal pareciera que en dicho reglamento se perfila mejor y se refuerza la jerarquía de estos funcionarios públicos en lo local, siempre supeditada a la jerarquía que le vincula con el poder central.

Para nuestros efectos, un último elemento relevante de la demarcación de la figura del juez de paz en las Ordenanzas de 1862 es su carácter restrictivo en términos de la ciudadanía, pues uno de los requisitos para ser juez de paz era ser costarricense en el ejercicio de los derechos de ciudadano, además de ser mayor de edad y vecino del Distrito $^{66}$ (Art. 101). Cinco años después, en las Ordenanzas Municipales de 1867, se establecieron como nuevos requisitos para el nombramiento de los jueces de paz el saber leer y escribir, y ser mayor de 25 años ${ }^{67}$. Requisitos similares se imponían para ser comisario (Art. 109), mientras que los del jefe político eran más restrictivos, pues se les pedía saber leer y escribir, ser mayor de veinticinco años, y además "poseer un capital en bienes propios que no baje de quinientos pesos" (Art. 80). Los requisitos más restrictivos se solicitaban al gobernador (Art. 49): además de ser costarricense, mayor de treinta años y de poseer un capital no menor a dos mil pesos, debía "tener capacidades á juicio del Poder Ejecutivo" y ser del "estado seglar"68.

Hasta donde he investigado, la figura de los jueces de paz se encontraba vigente en la administración de León Cortés, tal y como establecen las Disposiciones legales relacionadas con el Gobierno Municipal publicadas en 1939 (Imprenta Nacional).

Ahora bien, ¿cuál fue la práctica de los jueces de paz, de los comisarios y policías en el terreno? A ellos dedico el siguiente apartado, en el cual, como se verá, representan la mayoría de funcionarios sobre los que dispongo información (31 de 38). No obstante, no he querido dejar pasar algunos detalles de los otros siete funcionarios, que podrían darnos otros elementos de juicio sobre la relevancia de la incorporación de hombres afrodescendientes a la función del Estado.

\footnotetext{
64 República de Costa Rica, 1874.

65 República de Costa Rica, 1872: 188.

66 Ibídem: 186.

67 República de Costa Rica, 1874: 90.

68 República de Costa Rica, 1872: 175.
} 


\section{Los afrocaribeños: funcionarios del Estado en la provincia de Limón}

Es necesario caracterizar brevemente a los sujetos de nuestro interés. A lo largo de mi trabajo de investigación, he podido identificar, en expedientes de homicidios y lesiones, documentos de Gobernación y de la Sección de Policía que se encuentran en el Archivo Nacional de Costa Rica, un total de 38 hombres afrodescendientes que laboraron como funcionarios públicos.

$\mathrm{Su}$ origen nacional y étnico ha sido establecido a partir de varios criterios: en primer lugar, en 28 casos sus nombres develan su origen afrocaribeño (Tabla 1), si seguimos los estudios de la historiadora norteamericana Lara Putnam para este lugar y esta época ${ }^{69}$. En otros 5 casos se explicita que se trata de jamaiquinos, que se consideraban súbditos británicos, lo que no excluye que otros se consideraran a sí mismos de esta misma manera, aunque las fuentes no lo expliciten en estos casos. Una persona más fue consignada como proviniente de las Indias "orientales", lo cual sugiere la posibilidad de que hubiese alguna migración, procedente de las Antillas británicas, de personas de origen indio. Como bien es sabido, por ese entonces la India era colonia del Imperio británico. Hay que agregar que un hombre más nació en Cartago, provincia del interior de Costa Rica, y que testigos lo identifican como "negro". Otro es de origen panameño, además, su nombre parece revelar, igualmente, su origen afrocaribeño. Finalmente, en otros dos casos, albergo algunas dudas: uno era un médico, profesión nada frecuente entre los afrocaribeños, si bien su nombre parece indicar dicha posibilidad (William Bross); otro, un gendarme, es consignado como José Welch, también poco frecuente entre los nombres afrocaribeños.

En términos geográficos, buena parte de los servidores públicos afrodescendientes que he podido ubicar cumplieron sus tareas en la ciudad de Limón, Matina, Siquirres y en el Caribe sur de Costa Rica (Bajo Urén, Sipurio, Old Harbor, Westfalia y Sixaola).

¿Cuáles fueron sus puestos como funcionarios públicos? La mayoría de ellos, un total de 20 , se desempeñó como policía y otra buena parte, un total de 11 , como juez de paz. También lo hiceron como intérpretes, escribientes, secretarios y, posiblemente, como médicos (Tabla 1). Los presupuestos de policía de Limón para varios meses de los años 1883, 1885 y 1886 nos brindan algunos indicios de las características que tuvo la incorporación de los hombres afrodescendientes contratados como policías o gendarmes, a partir de varios elementos: la formalidad, el carácter asalariado, la equivalencia salarial, la continuidad en el puesto y el lugar jerárquico dependiendo del tipo de puesto ocupado ${ }^{70}$.

69 Putnam, 2002.

70 Lista de empleados de la policía de Limón. Costa Rica, junio 1883. ANCR. SECPOL, Exp. 4796 bis, s.f.; Lista de empleados de la policía de Limón. Costa Rica, agosto 1883. ANCR. SECPOL, Exp. 4762, s.f.; Lista de empleados de la policía de Limón. Costa Rica, septiembre 1883. ANCR. SECPOL, Exp. 4760, s.f.; Lista de empleados de la policía de Limón. Costa Rica, octubre 1883. ANCR. SECPOL, Exp. 4761, s.f.; Lista de empleados de la policía de Limón. Costa Rica, diciembre 1883. ANCR. SECPOL, Exp. 4784 bis, s.f.; Lista de empleados de la policía de Limón. Costa Rica, enero-diciembre 1885. ANCR. SECPOL, Exp. 5161, s.f.; Lista de empleados de la policía de Limón. Costa Rica, septiembre 1886. ANCR. SECPOL, Exp. 5157, s.f.; Lista de empleados de la policía de Limón. Costa Rica, octubre 1886. ANCR. SECPOL, Exp. 5168, s.f.; Lista de empleados de la policía de Limón. Costa Rica, noviembre 1886. ANCR. SECPOL, Exp. 5155, s.f. 
Tabla 1. Limón: Número de hombres afrodescendientes en la función pública: criterios de definición de origen étnico y puestos desempeñados, 1880-1921, cifras absolutas ${ }^{71}$.

\begin{tabular}{|l|c|}
\hline $\begin{array}{l}\text { Criterio para establecer el origen étnico de hombres } \\
\text { afrodescendientes. }\end{array}$ \\
\hline Nacionalidad jamaiquina & 6 \\
\hline \multicolumn{1}{|c|}{ Indias Occidentales/súbdito británico } & \\
\hline Nacionalidad panameña & 1 \\
\hline \multicolumn{1}{|l}{+ nombre } & 28 \\
\hline Nombre & 1 \\
\hline Consignado por terceros & 2 \\
\hline Con dudas & $\mathbf{3 8}$ \\
\hline Total & 11 \\
\hline \hline $\begin{array}{l}\text { Puestos ocupados en el servicio de la función pública } \\
\text { de hombres afrodes. }\end{array}$ & 20 \\
\hline Juez de paz & 1 \\
\hline Policía/gendarme/comisario & 1 \\
\hline Escribiente e intérprete & 3 \\
\hline Intérprete bribri-esp. & 1 \\
\hline Empírico & 1 \\
\hline Médico de pueblo & $\mathbf{3 8}$ \\
\hline Secretario & \\
\hline Total & \\
\hline
\end{tabular}

71 Fuente: elaboración propia con base en: Lista de empleados de la policía de Limón. Costa Rica, junio 1883. ANCR. Sección Policía (en adelante SECPOL), Exp. 4796 bis, sin folio (en adelante s.f.); Lista de empleados de la policía de Limón. Costa Rica, agosto 1883. ANCR. SECPOL, Exp. 4762, s.f.; Lista de empleados de la policía de Limón. Costa Rica, septiembre 1883. ANCR. SECPOL, Exp. 4760, s.f.; Lista de empleados de la policía de Limón. Costa Rica, octubre 1883. ANCR. SECPOL, Exp. 4761, s.f.; Lista de empleados de la policía de Limón. Costa Rica, diciembre 1883. ANCR. SECPOL, Exp. 4784 bis, s.f.; Lista de empleados de la policía de Limón. Costa Rica, enero-diciembre 1885. ANCR. SECPOL, Exp. 5161, s.f.; Lista de empleados de la policía de Limón. Costa Rica, septiembre 1886. ANCR. SECPOL, Exp. 5157, s.f.; Lista de empleados de la policía de Limón. Costa Rica, octubre 1886. ANCR. SECPOL, Exp. 5158, s.f.; Oficio enviado por Juez de Paz al Gobernador de Limón. Costa Rica, 1887, ANCR. Ministerio de Gobernación (en adelante MG), Exp. 30654, f. 6; Oficio enviado por Agencia de Policía de Matina al Gobernador de Limón. Costa Rica, 1893. ANCR. MG, 27765, f. 1; Carta enviada por vecinos del barrio de Cieneguita al Gobernador de Limón contra David Fisher. Costa Rica, 1899. ANCR. MG, Exp. 29907, folios (en adelante ff.) 3 y 5; Juicio por el homicidio de Guillermo Hall. Costa Rica, 1900. ANCR. LJCC, Exp. 73, f. 1; Juicio por el homicidio de Hilario Mayorga. Costa Rica, 1902 ANCR. LJCC, Exp. 421, f. 4.; Juicio por el homicidio de Juan Ramos. Costa Rica, 1902. ANCR. LJCC, Exp. 441, ff. 1 y 3; Juicio por el homicidio de Ramón Hernández Tea. Costa Rica, 1904. ANCR. LJCC, Exp. 109, f. 1; Juicio por las lesiones ocasionadas a Daniel William y a Crispín Ramírez. Costa Rica, 1912. ANCR. Limón Juzgado del Crimen (en adelante LJC), Exp. 396, ff. 4 y 5; Juicio por el homicidio de José Rojas. Costa Rica, 1914. ANCR. LJCC, Exp. 912, f. 11; Juicio por el homicidio de Margarita Pelton. Costa Rica, 1912. ANCR. LJCC, Exp. 409, f. 5; Juicio por el homicidio de William Nixon. Costa Rica, 1915. ANCR. LJCC, Exp. 901, f. 1.; Juicio por las lesiones ocasionadas a Alfredo Sealy. Costa Rica, 1912. ANCR. LJC, Exp. 358, f. 6; Juicio por las lesiones ocasionadas a James William Thompson. Costa Rica, 1921. ANCR. LJC, 1266, f. 10; Carta enviada por vecinos del barrio de Cieneguita al Gobernador de Limón recomendando a Samuel Grant. Costa Rica, 1921. ANCR. MG, Exp. 57890, f. 12. 
Habría que señalar que en estos registros presupuestarios se hacía constar el carácter de asalariado de varias clasificaciones de policías, como el agente principal, los agentes de policía, los gendarmes-marineros, los gendarmes a secas; la dotación mensual -es decir, el salario correspondiente al puesto-; los días servidos y el sueldo devengado de acuerdo a los días servidos en cada mes. Dependiendo del mes, la nómina pudo tener hasta 20 funcionarios, incluido el médico de pueblo ${ }^{72}$.

Para nuestros efectos, el primer elemento significativo de este registro es que varios de los funcionarios eran afrodescendientes: Federico Estuard, Charles Eduard, Samueel Williams, Constantin Jacoby, John Brenan, Francisco Spencer, Henry Smith y Alberly Broual, son los nombres que más frecuentemente aparecen en dichos registros ${ }^{73}$.

El segundo elemento relevante es la continuidad laboral de varios de estos funcionarios, detectable en los veinte presupuestos mensuales de policía que disponemos. Jacoby aparece en los veinte presupuestos, seguido por Williams, que figura en diecisiete y Ateles, en once de ellos. Los otros aparecen considerablemente menos, hasta un máximo de 3 veces. Resulta muy llamativo la presencia de un nombre de origen anglófono, quien ocupa el puesto de médico de pueblo en dieciséis de los presupuestos: William R. Bross ${ }^{74}$.

El cuarto aspecto digno de mención es que al mismo tipo de empleo correspondió la misma dotación mensual, independientemente del origen étnico. En el presupuesto de 1883, por ejemplo, la dotación que se consigna para Charles Eduard y José María Cordero es de 30 pesos, por desempeñarse bajo la categoría de "gendarme y marinero" 75 . Napoleón Zeledón y Samuel Williams fueron empleados como "gendarmes", y cada uno recibió por su desempeño 25 pesos $^{76}$. Dos categorías salariales eran superiores a las ya mencionadas: la del agente principal de policía, quien recibió ese año 60 pesos, y la del médico de pueblo, cuya dotación fue de $90^{77}$. En este último caso, quien desempeñó el puesto fue Rodolfo Alvarado, pero en el mes de octubre de 1883, dos cambios experimentó la plaza: una mejor dotación mensual, de 100 pesos, y el nombramiento de W.R. Bross ${ }^{78}$, posiblemente afrodescendiente, y sobre quien no contamos con más datos. De ninguna información disponemos sobre la satisfacción que los funcionarios afrodescendientes tuvieron con sus puestos y sus salarios, lo único que podemos asumir, tentativamente, es que en lo formal debió ser equivalente al de los mestizos.

El quinto aspecto a resaltar de estos presupuestos de policía es que el cargo de mayor jerarquía y mayor dotación mensual -a excepción del salario del médico de pueblo-, fue ocupado, durante todo el período estudiado, por un mestizo: José Ferandez Rodríguez. No poco relevante es que los gendarmes de origen afrodescendiente nunca superaron la cuarta parte del total de empleados.

La última afirmación -la referente a la proporcionalidad-nos lleva a señalar uno de los límites de este artículo: con el fin de comprender si la participación de los

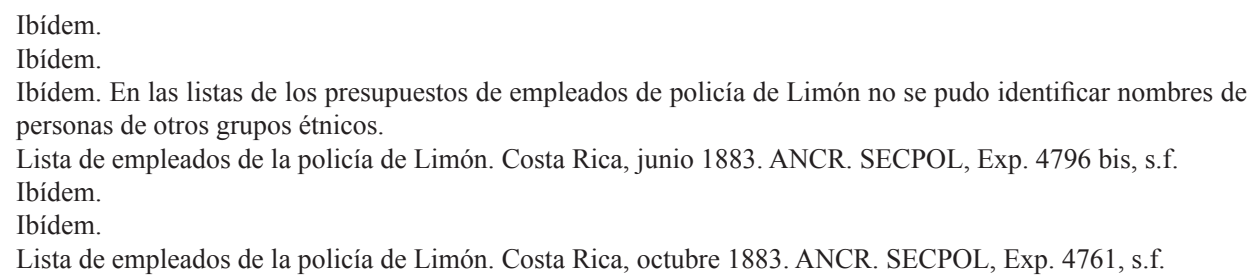


afrodescendientes fue proporcional al peso de su población de origen, sería necesario comparar el peso de los funcionarios públicos de uno y otro origen, como proporción de cada una de sus poblaciones durante el período estudiado. Ello comporta una investigación de mayor aliento, que aún está pendiente y que superaría, en todo caso, la extensión disponible.

Ahora bien, el papel jugado por los intérpretes y por los empíricos en la función pública era, más bien, puntual y en tanto fueran requeridos por las autoridades. Es el caso de Bolvin Smith, agricultor de Sipurio de Talamanca, quien fue mandado a llamar por William Smith, el juez de paz de Bajo Urén, para servir de intérprete del bribri al español, en un caso que involucraba a hombres y mujeres indígenas. Las zonas de Sipurio y Bajo Urén, cabe acotar, son territorios indígenas, lo que muestra la integración de Bolvin Smith, quien seguramente era trilingüe ${ }^{79}$.

Por su parte, William Aitlen y Alfred Blake, agricultores de Siquirres, fueron nombrados por la Agencia Principal de Policía de Siquirres en el caso del asesinato del nicaragüense Hilario Mayorga ${ }^{80}$. A falta de médicos de pueblo, cualquier sujeto podía ser llamado a desempeñar labores forenses. En su dictamen, Aitlen y Blake consignaron que el cuerpo de Mayorga "presentó cuatro heridas del modo siguiente: una en el pecho bastante profunda, otra en la cara, otra en la cabeza y otra en la espalda, causadas con instrumento cortante y opinamos que le produjo la muerte la herida del pecho por ser mortal"»1.

A mi parecer, lo ocasional del trabajo realizado por intérpretes y empíricos no debe llevarnos a despreciar un hecho fundamental: eran legitimados por la institucionalidad para cumplir labores propias de la función pública del Estado costarricense.

Ciertamente, la función de los jueces de paz, de los policías y los escribientes tenía una inserción más estable dentro de la cosa pública, con salarios establecidos en los presupuestos municipales. Esto según los reglamentos de policía y ordenanzas municipales antes citados.

Por ahora, he avanzado particularmente en el escrutinio de las labores de los jueces de paz, sobre lo que quisiera señalar algunas líneas generales. La correspondencia que corre entre la Secretaría de Gobernación y Policía, la gobernación de Limón y los jueces de paz nos brinda una primera idea. Los jueces de paz informaban sobre el cobro de las patentes comerciales -entre ellas, las de tabaco y licores- y su adecuado orden, sobre la buena salud -ignoro de quién-, sobre el estado del clima, sobre los varones en ciertos rangos de edad que habitaban su jurisdicción -con fines que ignoro-, y en ocasiones tenían "el gusto de informar" sobre la paz y el orden de su jurisdicción ${ }^{82}$.

Los expedientes de homicidio y lesiones muestran, por otra parte, que las labores de los jueces de paz podían ser de mayor riesgo. Así fue para los jueces Alfred Blake, Davis Shergols Stewart, y Santiago Carlos Hilead, quienes -según sus propias declaraciones- salieron a la captura de los presuntos ofensores -no siempre de manera

\footnotetext{
Juicio por el homicidio de Ramón Hernández Tea. Costa Rica, 1904. ANCR. LJCC, Exp. 109, f. 1. Juicio por el homicidio de Hilario Mayorga. Costa Rica, 1902 ANCR. LJCC, Exp. 421, f. 4.

Ibídem.

82 Oficio enviado por Juez de Paz al Gobernador de Limón remitiendo lista de varones mayores de veinte años. Costa Rica, 1887. ANCR. MG, Exp. 30654, f. 6; Oficio enviado por Juez de Paz al Gobernador de Limón informando sobre situación del lugar. Costa Rica, 1907. ANCR. MG, Exp. 40629, f. 1; Carta enviada por vecinos del barrio de Cieneguita al Gobernador de Limón contra David Fisher. Costa Rica, 1899. ANCR. MG, Exp. 29907, f. 5.
} 
exitosa. También fue el caso del comisario Justale Alborger Tolly, quien capturó a un hombre que había hecho un disparo con escopeta ${ }^{83}$.

La labor de captura pareciera revelar la importancia del cargo, pues en uno de los casos, Davis Shergols debió capturar al jefe del Resguardo de Policía de Puerto Viejo, seguramente un costarricense. En otro suceso ocurrido en Limón, el policía de la Subinspección de Hacienda Thomas Washington declaró en un juicio en contra de uno de los policías del Resguardo de Limón, posiblemente también costarricense, por disparar a otro hombre. Mientras que el policía de Limón fue declarado culpable, el caso del jefe de policía de Puerto Viejo prescribió, posiblemente por su mayor relevancia jerárquica. De cualquier manera, era evidente la importancia del ejercicio de la función pública por parte de los hombres afrodescendientes.

Los jueces de paz y comisarios también fungieron como declarantes en los procesos judiciales en su calidad de funcionarios públicos. En otros momentos interpusieron sus oficios para trasladar a los ofensores o apoyaron el buen desarrollo de los juicios.

En un contexto multiétnico como el de Limón de finales del siglo XIX e inicios del XX, en estos procesos judiciales estuvieron involucrados personas de múltiples orígenes, tales como Jamaica, Barbados, Italia, los Estados Unidos, Puerto Rico, Honduras, Colombia, Panamá, Nicaragua, El Salvador y Costa Rica ${ }^{84}$. Por ello, resulta relevante anotar que en cuatro de los once procesos judiciales estudiados, es posible observar la participación de más de un hombre afrodescendiente en su calidad de servidores públicos.

Esta confluencia multinacional llegó a la función pública. En los dos juicios contra policías de origen mestizo antes descritos, los ofensores estaban acusados de disparar a hombres afrodescendientes. La declaración de uno de los policías del Resguardo Fiscal de Puerto Viejo apuntó al cabo Peregrino Gómez, su superior, quien "se dirigió al establecimiento para retirar [...] á muchos jamaiquinos que estaban embriagados" $"$. Uno de ellos se había resistido al arresto y había sido auxiliado por otros paisanos. Algunos de los "jamaiquinos" habían seguido al jefe del Resguardo, Peregrino Gómez, portando rifles y cuchillos. Gómez había herido a uno de ellos. El caso más claro de racismo se aprecia en la declaración del propio imputado por lesiones, el policía Leonidas Díaz Castro. Según dijo, fue a una cantina en Cieneguita

Como en ese lugar, especialmente en la esquina aludida se forman con frecuencia grupos de más de treinta negros, procedí á retirarlos de allí y continué siempre recorriendo mi línea y antes de llegar al puente como á unas doce varas un jamaicano se me enfrentó $[\ldots]$ me voló una trompada que no me pegó $[\ldots]$ vi que el jamaicano recogía una piedra y sabiendo lo que son, saqué mi revolver y le disparé un tiro con que llamar á la policía que llegar á mi auxilio ${ }^{86}$.

\footnotetext{
83 Juicio por el homicidio de Juan Ramos. Costa Rica, 1902. ANCR. LJCC, Exp. 441, ff. 1 y 3; Juicio por el homicidio de Ramón Hernández Tea. Costa Rica, 1904. ANCR. LJCC, Exp. 109, f. 1; Juicio por las lesiones ocasionadas a Daniel William y a Crispín Ramírez. Costa Rica, 1912. ANCR. LJC, Exp. 396, f. 5; Juicio por las lesiones ocasionadas a James William Thompson. Costa Rica, 1921. ANCR. LJC, 1266, f. 10.

84 Viales, 1998.

85 Juicio por las lesiones ocasionadas a Daniel William y a Crispín Ramírez. Costa Rica, 1912. ANCR. LJC, Exp. 396, f. 11.

${ }^{86}$ Juicio por las lesiones ocasionadas a Alfredo Sealy. Costa Rica, 1912. ANCR. LJC, Exp. 358, f. 3.
} 
Como señalé con anterioridad, el policía de la Subinspección de Hacienda, Tomás Washington, declaró que el hombre de Barbados no había hecho cosa alguna en contra del policía Leonidas Díaz. El juez de paz de Puerto Viejo, por su parte, había girado una orden de detención del jefe del Resguardo, y no contra los jamaiquinos que supuestamente lo buscaban para agredirlo.

Un aspecto de particular relevancia vinculado a la incorporación de hombres afrodescendientes a la función pública fue la gestión emprendida por las comunidades. Así, por ejemplo, en 1907 un grupo de vecinos de Estrada de Limón, entre los que figuraban nombres de personas afrocaribeñas, socilitaron al ministro de Gobernación ascender el estatus de la "Agencia de policía" a "Agencia Principal de Policía", lo cual no sólo cubriría la necesidad de más agentes, sino que haría justicia a las "fuertes sumas" que los proponentes de la iniciativa pagaban ${ }^{87}$. ¿Cómo puede ser analizada esta demanda? Todo apunta a que se percibían como sujetos de derecho, en virtud de su compromiso con el erario público. ¿De aquí podría seguirse una noción cercana a la ciudadanía? No es del todo explícita esta posibilidad, ciertamente, y la única evidencia hasta ahora encontrada tiene el inconveniente de ser del año 1932, ocho años fuera de nuestro período. Se trata de una carta dirigida al ministro de Policía, a quien se pedía eliminar los obstáculos para el destace de ganado procedente de Cartagena ${ }^{88}$. Entre las 45 personas firmantes, puede apreciarse a varios afrodescendientes (R.B. Haylock, Davison, Thomas, Stanley Lindo, Percy Lindo, Barret), quienes pedían que se compartiera con ellos "la equidad y justicia á que tenemos derecho como ciudadanos" ${ }^{\prime 99}$. Este autoreconocimiento como ciudadanos, ciertamente posterior a nuestro período, puede ser visto como parte de este proceso, sin duda contradictorio, de construcción temprana de la ciudadanía afrocostarricense.

Las comunidades también fueron proactivas en el nombramiento y remoción de jueces de paz de su misma nacionalidad. Así, en agosto de 1899, un grupo de pobladores de Cieneguita y de Bananito, ciudad de Limón, pidieron a Balvanero Vargas, entonces gobernador de la Comarca, que removiera a David Fisher del puesto de juez de paz. Según indicaron, su paisano ya había ocupado el cargo con anterioridad, para ser luego removido "por sus malos precedentes". Fisher: "además de haber cometido muchos abusos cuando estaba de 'Juez de Paz', es criminal ante la ley y la Sociedad; por haber prostituido a la mujer de su hijo; y nosotros [...] no lo admitimos en nuestra Comunidad" 90 .

Alrededor de 14 años después, en la misma comunidad de Cieneguita de Limón, más de 20 personas de origen afrocaribeño se dirigían al gobernador de la ahora provincia. Le exponían la situación de los alrededores de Cieneguita, en donde "tienen su residencia gentes de mal vivir con cuya vida licenciosa causan continuamente escándalos, y perjudican las propiedades nuestras, con repetidos hurtos de gallinas y otras cosas" $"$. Ante la falta de autoridades en su barrio, recomendaban a Samuel

87 Carta de vecinos de Estrada de Limón al Ministro de Gobernación solicitando creación de Agencia Principal de Policía. Costa Rica, 1907. ANCR. SECPOL, Exp. 1471, ff. 1-3.

88 Carta de vecinos de Limón al Ministro de Gobernación solicitando se permita el destace de ganado proveniente de Cartagena. Costa Rica, 1932. SECPOL, Exp. 57767, s.f.

89 Ibídem.

90 Carta enviada por vecinos del barrio de Cieneguita al Gobernador de Limón contra David Fisher. Costa Rica, 1899. ANCR. MG, Exp. 29907, f. 5.

91 Carta enviada por vecinos del barrio de Cieneguita al Gobernador de Limón recomendando a Samuel Grant. Costa Rica, 1921. ANCR. MG, Exp. 57890, f. 12. 
Grant, "jamaicano y de nuestro vecindario, quien por sus dotes de honradez intachable, formalidad y seriedad a toda prueba y respeto que su edad infunde, llenaría a satisfacción de todos los vecinos, las funciones de Juez de Paz en este vecindario, para seguridad de nuestras vidas y garantía de nuestras propiedades" 92 .Ignoramos la respuesta del gobernador Vargas en el primer caso. Pero en este último, el resultado fue favorable a la petición de los vecinos de Cieneguita.

Ahora bien, en la solicitud comunitaria de remoción de David Fisher, puede apreciarse que las relaciones no siempre fueron armoniosas entre los funcionarios afrodescendientes y sus comunidades de origen. En este caso, lo que salía a la luz era el reclamo por sus malos precedentes. La causa que interpuso el jamaicano Willam Alexander Sevaby ante el gobernador de Limón, contra el juez de paz Noe Harkins ${ }^{93}$, es otro ejemplo de dicha conflictividad. Sevaby acusó a Harkins de abusar de su puesto al "despojarlo" de su propiedad, como también lo había hecho con otros vecinos. La conflictividad también pudo trascender los límites de la comunidad afrodescendiente, como lo demuestra la queja, también ante el gobernador, que interpusieron Cayetano, Celio y Ramón, "indios avecinados en las riveras del río Banano", por molestar y abusar de su autoridad con aquellos "los de raza indígena" 94 . Como puede observarse, las respuestas de los agraviados en algunos casos fueron llevadas a los cauces institucionales, lo que podría mostrar cierta legitimidad de las autoridades provinciales o, al menos, la expectiativa de que pudiesen resolver sus demandas, lo cual podría apuntar a la existencia de alguna cierta adhesión al funcionamiento institucional y la autopercepción como sujetos de derecho en este Estado nación.

En suma, hay evidencia que indica que los afrocaribeños asentados en el Caribe costarricense procuraron incidir sobre el nombramiento y remoción de funcionarios públicos de su misma comunidad y origen. Aún más, estas solicitudes fueron atendidas por los representantes de la institucionalidad del Estado. Quizá no sea ocioso señalar una nota fechada en noviembre de 1885, firmada por la Secretaría de Gobernación y Policía, es decir, la más alta instancia del Poder Ejecutivo, para que el gobernador de la Comarca de Limón buscara personas "competentes para el desempeño de las funciones de Juez de Paz" en la costa de esta comarca hacia el río Colorado ${ }^{95}$. Francisco Castro, quien probablemente estaba a cargo de la Agencia de Policía de Matina, dirigió unos años después (1893) una carta elocuente en este sentido al gobernador de la Comarca de Limón. En ella proponía al gobernador tres nombres de origen afrocaribeño (Guillermo Didegran, Walter Smith y Tomas Povrill) para que fungieran como jueces de paz en tres comunidades de Limón, la cual se remitía "en contestación" a la solicitud hecha por el gobernador mismo ${ }^{96}$. De tal suerte, el accionar de la gobernación a favor de la petición comunal, así como su proactividad en la búsqueda, parece indicar este movimiento de pinzas en el que confluyen las necesidades del proceso de expansión del Estado impulsado desde "arriba" con las demandas planteadas desde "abajo".

\footnotetext{
92 Ibídem.

93 Causa contra el juez de paz de Sixaola Noe Harkins por abuso de autoridad. Costa Rica, 1906. ANCR. MG, Exp. 57914, f. 1.

94 Carta al Gobernador de Limón denunciando abusos del agente de policía de Banano contra indígenas. Costa Rica, 1893. ANCR. MG, Exp. 27765, f. 4.

95 Oficio enviado por la Secretaría de Gobernación y Policía al Gobernador de Limón. Costa Rica, 1885. ANCR. MG, Exp. 39556, s.f.

96 Oficio enviado por Agencia de Policía de Matina al Gobernador de Limón. Costa Rica, 1893. ANCR. MG, Exp. 27765 , f. 1 .
} 
¿Cómo entender esta serie de evidencias durante este período que he denominado como de gestión temprana de la ciudadanía? Esto obliga a una breve discusión teórica.

\section{La construcción de la ciudadanía: un proceso contradictorio}

Es claro que la ciudadanía puede abarcar a algunos sectores de población y a otros no, y que algunos pueden estar sólo parcialmente cubiertos por dicho estatus. Esto implica asumir como punto de partida la crítica a la pretendida universalidad de la ciudadanía. Como señala Virginia Vargas, "la universalidad ha invisibilizado a las mujeres y a todos los demás sectores excluidos del modelo cultural hegemónico" $" 97$.

Pero esta definición tan general nos lleva a correr el riesgo de no ver los pequeños detalles de la cotidianidad que develan una realidad contradictoria. Así, siguiendo a Maxine Molyneux ${ }^{98}$, si bien un primer punto crucial para el análisis de la ciudadanía es determinar el carácter del Estado en cada momento histórico, reducir la mirada a lo local permite ver la incidencia de los grupos de presión y las mismas decisiones que emanan del Estado en sus dinámicas específicas.

A este respecto, el concepto de ciudadanía que Nira Yuval Davis ha retomando de Thomas H. Marshall brinda una útil aproximación. La ciudadanía, según Marshall, aludiría a "una condición conferida a aquellos que son miembros plenos de una comunidad' [...] lo cual incluye los derechos civiles, políticos y sociales"99. Esta definición resulta de gran utilidad, pues consideraría a los ciudadanos y ciudadanas no sólo en su relación individual frente al Estado, sino a partir de su pertenencia a una comunidad más específica (la afrodescendiente, en nuestro caso). Sin embargo, este concepto ha sido criticado porque la comunidad no es necesariamente homogénea y resulta problemático asumir un bien común que represente los intereses comunes de toda la comunidad, cuando éstos pueden ser dominados por una elite ${ }^{100}$.

Incorporando esta llamada de atención, la definición de Marshall presenta como ventaja la comparación. Es decir, facilita el entendimiento de cuáles son los criterios bajo los cuales un grupo de población se encuentra integrado a una comunidad, y si se encuentra plena o parcialmente integrado. Este grado de integración se establece en la comparación respecto de aquéllos que sí se encuentran plenamente integrados.

Lo dicho nos permite sostener, por una parte, que el proceso de construcción de la ciudadanía dista de ser unilineal o unidireccional. Por otra parte, que es de especial relevancia estudiar el punto en que convergen las estrategias desarrolladas por los agentes y el Estado nacional, a lo cual Molyneux designa como espacios institucionales. Es decir, se trataría de instituciones de tipo legal, político-administrativo y cultural cuyas normativas y prácticas reflejan este proceso de confluencia o de conflicto y, por lo tanto, brindan una aproximación a la forma que adquiere la ciudadanía de una población, y cuyo análisis a través del tiempo nos ofrece una imagen de su evolución.

Este doble influjo que adquiere la dinámica de la construcción de la ciudadanía puede resultar en tres tipos de dinámicas desde las cuales se puede experimentar el

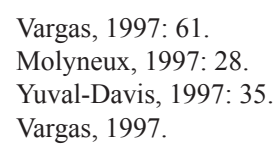


desarrollo y la expansión de los derechos. Según Virginia Vargas ${ }^{101}$, este desarrollo se puede producir desde abajo, por presión de las y los agentes, puede también generarse desde arriba, por decisión de la elite dominante o por combinación de ambas dinámicas.

De esta suerte, la evidencia antes presentada parece apuntar a que este período que he denominado como de gestión temprana de la ciudadanía puede ser visto como un proceso, ciertamente inacabado, de combinación de la dinámica de construcción de la ciudanía desde abajo y desde arriba a través de la incorporación de la población afrodescendiente al Estado en calidad de funcionarios. Inacabado, debo enfatizar, en la medida en que, como se puede apreciar de la evidencia disponible, ello no se tradujo en la adquisición formal de la ciudadanía, si bien sí de ciertos derechos que de ella se derivan, tales como el empleo en puestos destinados a costarricenses.

Pero, ¿por qué contratar a funcionarios afrodescendientes? No disponemos de una explicación definitiva. Hay indicios de una gestión "desde abajo" que muestra la importancia de la comunidad en esta materia, así como la autopercepción como sujetos de derecho ante el Estado. También existen pruebas de que algunos funcionarios mestizos recomendaron a hombres afrodescendientes para desempeñarse en puestos del Estado en lo local. Una pregunta de mayor alcance es si la integración de estos hombres afrodescendientes en el Estado era parte de una estrategia de control de estas poblaciones, y, siendo así, si el movimiento de pinza "desde arriba" hubiera podido operar bajo esta lógica. Por ahora, únicamente podríamos proponer que ello pudo ser así, lo cual encuentra parangón con una veta aún más estudiada: a finales del siglo XX, el Estado buscó coptar a los pueblos indígenas, dando a los reyes bribris el título de jefes políticos ${ }^{102}$. El que esta misma dinámica operara en el caso de las comunidades afrodescendientes sería, por ahora, no más que una hipótesis. En todo caso, ambas dinámicas no son mutuamente excluyentes, y podrían ser parte de una explicación de mayor complejidad, como suele ser la realidad que estudiamos.

\section{Conclusiones}

Como ya otros autores lo han señalado, en la época liberal, de la cual el período aquí estudiado es parte, las élites tuvieron una gran apertura en cuanto a la incorporación de extranjeros en la vida económica de la nación costarricense. Tiende a estar más establecido en la literatura que estudia este momento, el particular interés que tuvieron en la población europea y blanca ${ }^{103}$.

Sin embargo, según las evidencias que arroja la presente investigación, no es despreciable la apertura de la elite liberal hacia la población aquí estudiada en materia de su incorporación al manejo del Estado en la provincia caribeña de Limón. No resulta ocioso remarcar las características de esta población, pues se trataba de extranjeros afrodescendientes sobre los que recaían prácticas y concepciones racistas. Adicionalmente, no puede dejar de considerarse que, sobre todo en los primeros tiempos, era una población que profesaba la religión protestante en un país predominantemente católico, que la mayoría era angloparlante o bilingüe, en un país cuyos

\footnotetext{
101 Ibídem: 61.

102 Boza, 2003.

103 Alvarenga, 2002.
} 
ciudadanos comunes hablaban sólo español y, aún más, que se consideraba a sí misma ciudadana del Imperio británico, en un país con un referente colonial español. En otras palabras, aún con las contradicciones del racismo de la época, el proyecto liberal del Estado nacional en el Caribe costarricense utilizó a esta población para afirmar su dominio del territorio y su gente.

Debe decirse que esta práctica utilitaria hacia los pueblos racializados no fue exclusiva de la población afrodescendiente, pues en la misma época la élite liberal estableció una alianza con los indígenas bribris de Talamanca, Caribe sur de Costa Rica, que perseguía consolidar el dominio sobre estas tierras, en un contexto de disputas limítrofes ${ }^{104}$. Tampoco puede despreciarse que las personas pertenecientes a estos pueblos aprovecharan estas alianzas para sus propios fines ${ }^{105}$. De tal suerte, aún con el peso de los diferentes componentes identitarios que parecían alejar a los afrocaribeños del suelo costarricense y, según ha señalado Quince Duncan ${ }^{106}$, de despreciar todo lo nacional-costarricense, fue claro su esfuerzo por integrarse por varias vías, entre ellas, la del trabajo asalariado como funcionarios, en lo local, de ese mismo Estado. Al aprovechar esta confluencia, tanto el Estado -desde "arriba"- como los afrodescendientes -desde "abajo"- construyeron un espacio social e institucional, sin duda contradictorio, que diluyó los contornos de su extranjería y su condición de sujetos racializados en un país racista, abriendo la posibilidad de que se desempeñaran como costarricenses en los puestos señalados. Ciertamente desempeñarse "como" ellos no significó tener su mismo estatus ciudadano, pero les abrió espacios en los que ciertos derechos propios de las personas costarricenses pudieron ser disfrutados.

Como señalé, los datos disponibles señalan que este proceso de contratación pudo estar más difundido entre 1880 e inicios del siglo XX, y que se diluyó aún antes de la ola racista que se abre en la década de 1930. Ello abre nuevas preguntas, vinculadas a los factores que pudieron producir estos cambios.

También quedan pendientes varios asuntos cruciales: ¿qué tan extendido y constante fue este proceso en la provincia de Limón durante el período en estudio? ¿Guardó alguna proporcionalidad el nombramiento de funcionarios afrodescendientes, respecto al peso de la población de su mismo origen en Limón? ¿Los nombramientos privilegiaron a un grupo o comunidad sobre otra? Nuevas investigaciones deberán desarrollarse.

Para finalizar, algunas personas nos han preguntado, ¿qué papel pudo tener la UFCo en la dinámica estudiada? A partir de los datos que poseemos, podría decirse que la lógica de la dinámica en que la comunidad afrodescendiente y el Estado se vincularon, así como la forma en que dentro de la misma institucionalidad algunos funcionarios mestizos recomendaron a hombres afrodescendientes, se muestra diferente a aquella dinámica impuesta por la UFCo estudiada por autores como Phillipe Bourgois ${ }^{107}$. A diferencia de lo que él encontró, los funcionarios afrodescendientes aquí estudiados no fueron la mayoría, y no ocuparon los mejores puestos dentro de la jerarquía estatal de Limón.

La conflictividad "étnica" entre comunidades de origen, ¿es similar a la que Bourgois encontró en la Bananera? A partir de nuestro análisis podemos decir que el

\footnotetext{
104 Boza, 2003.

105 Menjívar, 2013.

106 Duncan - Meléndez, 2005.

107 Bourgois, 1989.
} 
hecho de que los afrodescendientes pudiesen intervenir en contra de mestizos parece responder a los atributos formales de su puesto en el Estado. Por otra parte, los casos de conflicto intracomunal entre afrodescendientes, así como de ciertos funcionarios de dicho origen con personas indígenas, estuvieron marcados por agravios de tipo económico y de orden moral. Para los efectos del presente análisis, que no parte de la categoría de "etnia", es posible pensar que estos elementos se articularon con la ideología de la raza que ya había sido elaborada en Costa Rica durante los primeros 50 años de vida independiente, y que a partir de 1870 los liberales se dieron a la tarea de subrayar ${ }^{108}$. En este sentido, se trata de una ideología que precede a la Bananera y que, con seguridad, fue aprovechada por la misma UFCo para sus propios fines.

Pero la pregunta que da origen a esta reflexión nos lleva a devolver una serie de interrogantes: ¿por qué solemos esperar que la UFCo determine la dinámica social de Limón en el período estudiado? Dicho de otra manera, ¿solemos asumir que toda relación social en el Caribe costarricense se desarrolló dentro de los dictados de la Compañía? Tiendo a pensar que hemos prestado menos atención de lo que debíamos a otras dinámicas sociales, más allá de la Bananera. Aunque ésa es una línea de reflexión que escapa a los propósitos del presente artículo, este trabajo puede ser una llamada de atención para que, sin despreciar la importancia que tuvo la UFCo, desplacemos nuestra mirada de aquel espacio al que hemos estado tan acostumbrados, para iluminar otras dinámicas sociales del Caribe que aún no han sido parte de nuestro foco de atención.

\section{Referencias bibliográficas}

Acuña, Víctor. "La invención de la diferencia costarricense, 1810-1870". Revista de Historia, $\mathrm{n}^{\circ} 45$ (2002), 191-228.

Alpizar, Leidy. "Rompiendo el mito: inserción social de los jamaiquinos en el Cantón Central de San José, entre 1904 y 1950”. Tesis de Maestría, Universidad de Costa Rica, 2017.

Alvarenga, Patricia. "La inmigración extranjera y la nación costarricense". Istmo, nº 4 (2002). Disponible en http://istmo.denison.edu/n04/articulos/inmigracion.html

Bourgois Philippe. Banano, etnia y lucha social en Centroamérica. San José: DEI, 1989.

Boza, Alejandra. "Política en la Talamanca indígena: El Estado nacional y los caciques. Costa Rica, 1840-1922". Anuario de Estudios Centroamericanos, vol. 29, n 1-2 (2003): 113-145.

Casey, Jeffrey. Limón 1880-1940: Un estudio de la industria bananera en Costa Rica. San José: Editorial Costa Rica, 1979.

Díaz Arias, David. Construcción de un Estado Moderno: política, estado e identidad nacional en Costa Rica, 1821-1914. San José: Editorial UCR, 2005.

- La era de la centralización: Estado, sociedad e institucionalidad en Costa Rica, 18481870. San José: Editorial UCR, 2015.

Duncan, Quince. Contra el racismo. San José: Euned, 2001

Duncan, Quince - Meléndez, Carlos. El negro en Costa Rica. San José: Editorial Costa Rica, 1981.

Harpelle, Ronald. "The social and political integration of West Indians in Costa Rica: 1930-50”. Journal of Latin American Studies, vol. 25 (1993), 103-120. DOI:10.1017/ S0022216X00000389

108 Acuña, 2002. 
- The West Indians of Costa Rica. Race, Class, and the Integration of an Ethnic Minority. Montreal: McGill-Queen's University Press, 2001.

Hernández, Omar. "De inmigrantes a ciudadanos: hacia un espacio político afrocostarricense (1949-1998)". Revista de Historia, no 39 (1999), 207-245.

Menjívar Ochoa, Mauricio. "Masculinidades Neo-Coloniales En Talamanca, Caribe Sur De Costa Rica (1898-1930)". Revista de Historia, no 68 (2013), 43-88. Disponible en https:// www.revistas.una.ac.cr/index.php/historia/article/view/6497

Molyneux, Maxine. "Debates sobre comunitarismo, moralidad y políticas de identidad". En La ciudadanía a debate, editado por Hola, Eugenia y Portugal, Ana Ma. Santiago: Isis Internacional, 1997, 15-33. Identidades de hierro y humo. La construcción del ferrocarril al Atlántico 1870-1890. San José: Editorial Porvenir, 1995.

Murillo, Carmen. "Vaivén de arraigos y desarraigos: identidad afrocaribeña en Costa Rica, 1870-1940". Revista de Historia, no. 39 (1999), 187-206.

Pérez Granados, Mónica. La construcción jurídica de la población afrocaribeña costarricense (1940-2014). San José: Editorial UCR, 2018.

Putnam, Lara. “¿Qué tan ajenos y qué tan extraneros?: Los antillanos británicos en América Central, 1880-1940”. En Nuestra herencia afrocaribeña. Colección Del olvido a la memoria $\mathrm{n}^{\circ} 5$, editado por Cáceres, Rina. San José: UNESCO-Universidad de Costa Rica, s.f., 22-36.

- The Company they kept. Migrants and the politics of gender in Caribbean Costa Rica, 1870-1960. Chapel Hill and London: The University of North Carolina Press, 2002.

Rosario Fernández, Reina. "Las identidades de la población de origen jamaiquino en el Caribe costarricense en la $2^{\mathrm{a}}$ mitad del siglo XX". Tesis Doctoral, Universidad de Costa Rica, 2014.

República de Costa Rica. Colección de las leyes, decretos expedidos por los supremos poderes Legislativo y Ejecutivo de Costa Rica en los años de 1849 y 1850, tomo XI. San José: Imprenta la Paz, 1865.

- Colección de las leyes, decretos expedidos por los supremos poderes Legislativo y Ejecutivo de Costa Rica en los años de 1861 y 1862, tomo XVII. San José: Imprenta la Paz, 1872.

- Colección de las leyes, decretos expedidos por los supremos poderes Legislativo y Ejecutivo de Costa Rica en los años de 1867 y 1868, tomo VII. San José: Imprenta la Paz, 1874.

Senior, Diana. Ciudadanía afrocostarricense. El gran escenario comprendido entre 1927 y 1963. San José: EUNED-Editorial UCR, 2011.

Vargas, Virginia. "Un debate feminista en curso". En La ciudadanía a debate, editado por Hola, Eugenia y Portugal, Ana Ma. Santiago, Chile: Isis Internacional, 1997, 55-69.

Vargas Arias, Claudio. Hacia la consolidación del Estado liberal en Costa Rica (1870-1890). San José: Editorial UCR, 2015.

Viales, Ronny. Después del enclave, 1927-1950. Editorial UCR, 1998.

Yuval-Davis, Nira "Mujeres, ciudadanía y diferencia". En La ciudadanía a debate, editado por Hola, Eugenia y Portugal, Ana Ma. Santiago, Chile: Isis Internacional, 1997, 35-53. 
